\title{
Insect Pests of Yard Long Bean (Vigna unguiculata subsp. sesquipedalis L.) in Major Growing Areas of Bangladesh
}

\author{
M. S. Uddin ${ }^{1}$, M. M. Rahman' 2 M. Z. $\mathrm{Alam}^{2}$, A. Awal ${ }^{3}$ and M. A. Mazed ${ }^{4}$ \\ ${ }^{I}$ Department of Agricultural Extension (DAE), Bamna, Barguna; ${ }^{2}$ Department of Entomology, \\ Bangabandhu Sheikh Mujibur Rahman Agricultural University, Gazipur-1706, Bangladesh; ${ }^{3}$ DAE, \\ Laxmichhari, Khagrachhari; ${ }^{4}$ DAE, Nasir Nagar, Brahmanbaria, Bangladesh \\ *Corresponding author and Email: shafiuddin.dae@gmail.com
}

Received: 04 February 2013 Accepted: 06 December 2013

\begin{abstract}
The survey was conducted in intensive yard long bean growing areas such as Jessore, Dhaka, Narsingdi, Comilla and Chittagong of Bangladesh to know the pest incidence and their level of infestation on yard long bean during March to October 2009. The study comprised of 75 sample farmers through intensive field visit for field data collection and inspection. Pest complex of yard long bean and their intensity of incidence were more or less similar in five surveyed areas and there were at least nine out of ten insect pests at different growth stages in each sample area, which were aphid, pod borer, thrips, red mite, leaf miner, leaf beetle, green sting-bug, jute hairy caterpillar, hooded hopper and semilooperin descending order. It was revealed that aphid and pod borer were the major insect pests in the study areas. They were found to severely infest in yard long beans. Semilooper caused minor damage which occurred only in Jessore, Chandina and Mirshawrai sample areas.
\end{abstract}

Keywords: Insect pest, yard long bean, Bangladesh

\section{Introduction}

Yard long bean (Vigna unguiculata subsp. sesquipedalis (L.) Walp) is an important leguminous vegetable grown very profitably all over Bangladesh. It is also known as asparagus bean, string bean, snake bean or vegetable cowpea (Purseglove, 1977). It is mostly grown in Chittagong, Chittagong Hill Tracts (CHTs), Faridpur, Noakhali, Comilla and Rangpur districts. At present, it is extensively grown in Dhaka, Chittagong, Comilla, Narsingdi, and Jessore districts and also other districts of Bangladesh. It is extensively grown in kharif season when there is shortage of vegetables supply in the market. A serving of $100 \mathrm{~g}$ of yard long bean contains 50 calories, $9.0 \mathrm{~g}$ of total carbohydrates, $3.0 \mathrm{~g}$ of proteins, $0.2 \mathrm{~g}$ total fat and $0.8 \mathrm{~g}$ of minerals (Anon., 2013). Yard long bean is one of the economically important vegetable crops in Bangladesh. The area occupied by this crop was 5857.49 ha and the production was $21348 \mathrm{t}$ during the year 20082009 (Anon., 2010). It is one of the vegetables having exporting potential in Bangladesh.

The cultivation of this crop faces various problems including the pest management (Rashid, 1993). Yard long bean is especially attractive to aphids (Aphis craccivora, Myzus persicae and Aphis gossypii), green stink bug (Nezara viridula) and red spider mite (Tetranychus spp.). Greasy cutworms (Agrotis ipsilon) often cause damage just after emergence 
(Grubben, 1993). The insect pests have been reported as one of the serious problems to yard long bean cultivation in the country (Rashid, 1999). However, their levels of infestation in different growing regions have not been reported so far. The pest complexes including the major ones are also not exactly known from the major growing areas. One of the major constraints for this bean production in Bangladesh is the attack of pod borer, Euchrysops cnejus (Dutta et al., 2004). Legume pod borers' populations have been found to reduce up to 100 percent of crop yields in pigeon pea in Bangladesh (Rahman et al., 1981). Aphid, the most destructive pest, causes damage by sucking sap from flowers, buds, pods and tender branches of the plants and reduces the viability of plant (Thaker et al., 1984). Reports on the insect pests' incidence and their management techniques for the yard long bean in its major growing areas of Bangladesh are scanty. The present survey was, therefore, undertaken to know the insect pest incidence and their level of infestation in yard long bean in the major growing areas of Bangladesh.

\section{Materials and Methods}

The survey was conducted in the farmers' field in five major growing areas of yard long bean such as Jessore (Jessore sadar), Dhaka (Savar), Narsingdi (Shibpur), Comilla (Chandina) and
Chittagong (Mirshawrai) during March to October 2009. The study comprised of sample farmers' survey and intensive field visit for field data collection and inspection.

\subsection{Selection of survey locations and their features}

Jessore sadar, Savar, Shibpur, Chandina and Mirshawrai are the intensive yard long bean growing upazillas of Jessore, Dhaka, Narsingdi, Comilla and Chittagong districts, respectively. One union was selected from each upazilla and from each selected union, one yard long bean field of which 15 sample farmers were randomly selected for the survey and inspection (Table 1). Selected farmer's fields are Natuapara of Haibathpur union under Jessore Sadar upazilla, Daywin of Birulia union under Savar upazilla, Ghasirdiah of Ieubpur union under Shibpur upazilla, Pihor of Borokuit union under Chandina upazilla and East Govnia of khuiyachora union of Mirshawrai upazilla. For this purpose, a list of yard long bean growers of the randomly selected location was prepared with the help of the Sub-Assistant Agricultural Officers (SAAOs) of the respective location. From the list of each location, 15 farmers were randomly selected. Thus, a total of 75 farmers were selected for interview and their individual plots were inspected for the survey (Table 1).

Table 1. Selected five sample locations for survey and their features

\begin{tabular}{|c|c|c|c|c|c|}
\hline $\begin{array}{l}\text { Locations of } \\
\text { Farmer's } \\
\text { field }\end{array}$ & $\begin{array}{c}\text { No. of } \\
\text { surveyed } \\
\text { farmers }\end{array}$ & Union & Upazila & District & $\begin{array}{c}\text { Agro- } \\
\text { ecological } \\
\text { zone }\end{array}$ \\
\hline Natuapara & 15 & Haibathpur & Jessore Sadar & Jessore & 11 \\
\hline Daywin & 15 & Birulia & Savar & Dhaka & 28 \\
\hline Ghasirdiah & 15 & Ieubpur & Shibpur & Narshingdi & 28 \\
\hline Pihor & 15 & Borokuit & Chandina & Comilla & 19 \\
\hline East Govnia & 15 & Khuiyachora & Mirshawrai & Chittagong & 23 \\
\hline
\end{tabular}




\subsection{Methods of data collection}

Data were collected directly from the sample farmers by administering pre designed and pre tested questionnaires (Instrument 1) and recording of data in pre-formatted register (Instrument II) was done at 15 days interval from the sample farmer's crop fields through field and crop observation.

In questionnaire survey, the researcher directly interviewed the sample farmers and collected data on overall cultivation practices including methods of pest control, insect pests incidence in general and major pests infestation, pod borers and aphid, in particular. In this context, data were collected by systematic sampling.

\subsection{Data processing and output generation}

All the collected data were coded, tabulated, checked and calculated by using simple statistical methods, e.g. mean percent etc.

\section{Results and Discussion}

\subsection{Cultivation of yard long bean}

Cultivation related data were collected directly from the sample farmers by administering predesigned questionnaire through field and crop observation.
Among the sample farmers, $26.67 \%$ cultivated yard long bean for1-4 years, $61.33 \%$ farmers cultivated yard long bean for last 5-10 years and the rest $12.00 \%$ farmers cultivated yard long bean for more than last 10 years. In case of variety used by the farmers, $25.33 \%$ farmers used their own preserved seeds and $74.67 \%$ farmers purchased seeds from market (Table 2).

In case of fertilizer application, $29.33 \%$ farmers applied fertilizer at a rate less than that of requirement, $49.34 \%$ farmers used required amount of fertilizers and $21.33 \%$ farmers applied excess quantity of fertilizers in the yard long bean field. On the other hand, 66.67\% yard long bean farmers applied organic manure and $33.33 \%$ farmers did not apply any organic manure in their fields (Table 3).

\subsection{Training on integrated pest management (IPM)}

On an average, $5.33 \%$ of the sample farmers received IPM training, whereas $94.67 \%$ did not receive any types of training. Among the sample farmers, only $6.67 \%$ farmers had knowledge about natural enemies (predators) of harmful insects while $73.34 \%$ farmers had no knowledge about natural enemies (Table 4).

Table 2. Cultivation (years) and varieties used by the respondents in different surveyed areas of Bangladesh

\begin{tabular}{|c|c|c|c|c|c|c|c|}
\hline \multicolumn{2}{|c|}{ Location } & \multicolumn{3}{|c|}{$\begin{array}{c}\text { (\%) Farmers' experience } \\
\text { of cultivation of yard long } \\
\text { bean (years) }\end{array}$} & \multicolumn{2}{|c|}{$\begin{array}{l}\text { Variety used by the } \\
\text { respondents (\%) }\end{array}$} & \multirow[t]{2}{*}{ Name of the variety } \\
\hline Districts & Upazilla & $1-4$ & $5-10$ & $>10$ & own & purchased & \\
\hline Jessore & $\begin{array}{l}\text { Jessore } \\
\text { sadar }\end{array}$ & 66.67 & 26.67 & 6.67 & 46.67 & 53.33 & $\begin{array}{l}\text { Kashem king, } \\
\text { kagarnati }\end{array}$ \\
\hline Dhaka & Savar & 33.33 & 53.33 & 13.34 & 33.33 & 66.67 & $\begin{array}{l}\text { Toki, lalbani, } \\
\text { BARI barbati } 1\end{array}$ \\
\hline Narsingdi & Shibpur & 20.00 & 73.33 & 6.67 & 13.33 & 86.67 & $\begin{array}{l}\text { BU barbati 1, toki, } \\
\text { BARI barbati } 1\end{array}$ \\
\hline Comilla & Chandina & 6.67 & 80.00 & 13.33 & 26.67 & 73.33 & $\begin{array}{l}\text { Greenfield, kagarnati, } \\
1070\end{array}$ \\
\hline Chittagong & Mirshawrai & 6.67 & 73.33 & 20.00 & 6.67 & 93.33 & $\begin{array}{l}\text { Banalata, toki, } \\
\text { kagarnati }\end{array}$ \\
\hline Mean & & 26.67 & 61.33 & 12.00 & 25.33 & 74.67 & \\
\hline
\end{tabular}


Table 3. Fertilizer and manure application in yard long bean farming by the farmers of surveyed areas of Bangladesh

\begin{tabular}{|c|c|c|c|c|c|c|}
\hline \multicolumn{2}{|c|}{ Location } & \multirow{2}{*}{$\begin{array}{l}\text { \% farmers } \\
\text { applied } \\
\text { fertilizer } \\
\text { < required }\end{array}$} & \multirow{2}{*}{$\begin{array}{l}\text { \% farmers } \\
\text { applied } \\
\text { required } \\
\text { fertilizer }\end{array}$} & \multirow{2}{*}{$\begin{array}{l}\text { \% farmers } \\
\text { applied } \\
\text { fertilizer } \\
>\text { required }\end{array}$} & \multirow{2}{*}{$\begin{array}{l}\% \text { farmers } \\
\text { applied } \\
\text { organic } \\
\text { manure }\end{array}$} & \multirow{2}{*}{$\begin{array}{l}\% \text { farmers } \\
\text { avoid } \\
\text { organic } \\
\text { manure } \\
\text { application }\end{array}$} \\
\hline Districts & Upazilla & & & & & \\
\hline Jessore & Jessore sadar & 20.00 & 53.34 & 26.66 & 73.33 & 26.67 \\
\hline Dhaka & Savar & 73.33 & 20.00 & 6.67 & 53.33 & 46.67 \\
\hline Narshingdi & Shibpur & 20.00 & 66.67 & 13.33 & 93.33 & 6.67 \\
\hline Comilla & Chandina & 26.67 & 60.00 & 13.33 & 66.67 & 33.33 \\
\hline Chittagong & Mirshawrai & 6.67 & 46.67 & 46.66 & 46.67 & 53.33 \\
\hline Mean & & 29.33 & 49.34 & 21.33 & 66.67 & 33.33 \\
\hline
\end{tabular}

Table 4. Knowledge about natural enemies and training on IPM among the respondents (of yard long bean) at surveyed areas of Bangladesh

\begin{tabular}{llcccc}
\hline \multicolumn{1}{c}{ Location } & $\begin{array}{c}\text { (\%) farmers } \\
\text { having } \\
\text { Knowledge } \\
\text { about natural } \\
\text { enemies }\end{array}$ & $\begin{array}{c}(\%) \text { farmers } \\
\text { having no } \\
\text { Knowledge about } \\
\text { natural enemies }\end{array}$ & $\begin{array}{c}(\%) \text { IPM } \\
\text { trained } \\
\text { farmers }\end{array}$ & $\begin{array}{c}(\%) \text { farmers } \\
\text { having no } \\
\text { training on } \\
\text { IPM }\end{array}$ \\
\hline Jessore & Jessoresadar & 13.33 & 86.67 & 13.33 & 86.67 \\
Dhaka & Savar & 0.00 & 100.00 & 0.00 & 100.00 \\
Narshingdi & Shibpur & 6.67 & 93.33 & 6.67 & 93.33 \\
Comilla & Chandina & 13.33 & 86.67 & 6.67 & 93.33 \\
Chittagong & Mirshawrai & 0.00 & 100.00 & 0.00 & 93.33 \\
\hline Mean & & 6.67 & 73.34 & 5.33 & 94.67 \\
\hline
\end{tabular}

\subsection{Pest complex of yard long bean and their intensity of incidence}

As presented in Table 5, semilooper, hooded hopper, jute hairy caterpillar and green sting bug rated their appearance and damage severity as rating 1 i.e, insignificant damage while green sting bug, leaf beetle, leaf miner, thrips and red mite were rated as rating 2 i.e, low damage. At the same time, pod borer and aphid were rated their appearance and damage severity in rating 8 and 9, respectively i.e., causing severe damage. Rating scale $1 \& 2$ rated as minor pests and rating scale $8 \& 9$ rated as major insect pests of yard long bean surveyed in five areas of Bangladesh. This rating scale was supported by the rating scale of Egho (2010), Litsinger et al. (1977) and after Jackai and Singh (1988), who conducted studies on legume insect pest complex.

Table 6 and Figure 1, indicate the pest complex of yard long bean, their level of incidence and damage severity. But they were very similar in 5 surveyed areas and there were at least 9 (nine) out of 10 (ten) insect pests at different growth stage in each sample area, which were listed in descending order based on their lowest intensity of incidence.

The description along with photographs of the insect pests appearing at different stages of the plant growth, nature of damage caused by them, and the pest status as observed by the farmers under their field condition are presented in Table 7. 
Table 5. Scale for rating the level of incidence and damage severity of insect pest complex of yard long bean in five surveyed areas of Bangladesh

\begin{tabular}{|c|c|c|c|c|c|}
\hline \multirow{2}{*}{$\begin{array}{l}\text { Name of pests (descending } \\
\text { order based on their lowest } \\
\text { density of incidence) }\end{array}$} & \multicolumn{2}{|r|}{ Level of incidence } & \multicolumn{2}{|c|}{ Damage severity } & \multirow[b]{2}{*}{ Status } \\
\hline & Rating & Appearance & Rating & damage & \\
\hline Semilooper $(0,1)$ & 1 & incidence is not always & 1 & $\begin{array}{l}\text { Very } \\
\text { insignificant } \\
\text { damage }\end{array}$ & Minor \\
\hline Hooded hopper $(1,2)$ & 1 & very low in number & 1 & $\begin{array}{l}\text { insignificant } \\
\text { damage }\end{array}$ & Minor \\
\hline Jute hairy caterpillar $(1,2)$ & 1 & very low in number & 1 & $\begin{array}{l}\text { insignificant } \\
\text { damage }\end{array}$ & Minor \\
\hline Green sting bug $(3,4)$ & 1 & very low in number & 1 & $\begin{array}{l}\text { insignificant } \\
\text { damage }\end{array}$ & Minor \\
\hline Leaf beetle $(4,5)$ & 2 & incidence in small number & 2 & Low damage & Minor \\
\hline Leaf miner $(5,6)$ & 2 & incidence in small number & 2 & Low damage & Minor \\
\hline Thrips $(7,8)$ & 2 & incidence in small number & 2 & Low damage & Minor \\
\hline Red mite $(7,8)$ & 2 & incidence in small number & 2 & Low damage & Minor \\
\hline Pod borer (9) & 8 & incidence in moderate no. & 8 & $\begin{array}{l}\text { severe } \\
\text { damage }\end{array}$ & Major \\
\hline Aphid (10) & 8 & incidence in high number & 9 & $\begin{array}{l}\text { severe } \\
\text { damage }\end{array}$ & Major \\
\hline
\end{tabular}

Table 6. Pest complex and their intensity of incidence of yard long bean in five surveyed areas of Bangladesh

\begin{tabular}{llllll}
\hline \multirow{2}{*}{ Item } & \multicolumn{4}{c}{ Pest complex and intensity of incidence in surveyed areas } \\
\cline { 2 - 5 } & Jessore sadar & Savar & Shibpur & Chandina & Mirshawrai \\
\hline Incidence & Semi-looper (1) & Hooded & Hooded & Semi-looper (1) & Semi-looper (1) \\
of insect & Hooded & hopper (1) & hopper (1) & Hooded & Hooded \\
pests at & hopper (2) & Green & Green & hopper (2) & hopper (2) \\
different & Green sting & sting bug (2) & sting bug (2) & Green & Jute hairy \\
growth & bug (3) & Jute hairy & Jute hairy & sting bug (3) & caterpillar(3) \\
stages & Jute hairy & caterpillar (3) & caterpillar (3) & Jute hairy & Green \\
(descendi & caterpillar (4) & Leaf beetle (4) & Leaf beetle (4) & caterpillar (4) & sting bug (4) \\
ng order & Leaf beetle (5) & Leaf miner (5) & Leaf miner (5) & Leaf miner (5) & Leaf beetle (5) \\
based on & Leaf miner (6) & Thrips (6) & Thrips (6) & Leaf beetle (6) & Leaf miner (6) \\
their & Thrips (7) & Red mite (7) & Red mite (7) & Thrips (7) & Thrips (7) \\
lowest & Red mite (8) & Pod borer (8) & Pod borer (8) & Red mite (8) & Red mite (8) \\
density of & Pod borer (9) & Aphid (9) & Aphid (9) & Pod borer (9) & Pod borer (9) \\
incidence) & Aphid (10) & & & Aphid (10) & Aphid (10) \\
& & & & & \\
\hline
\end{tabular}




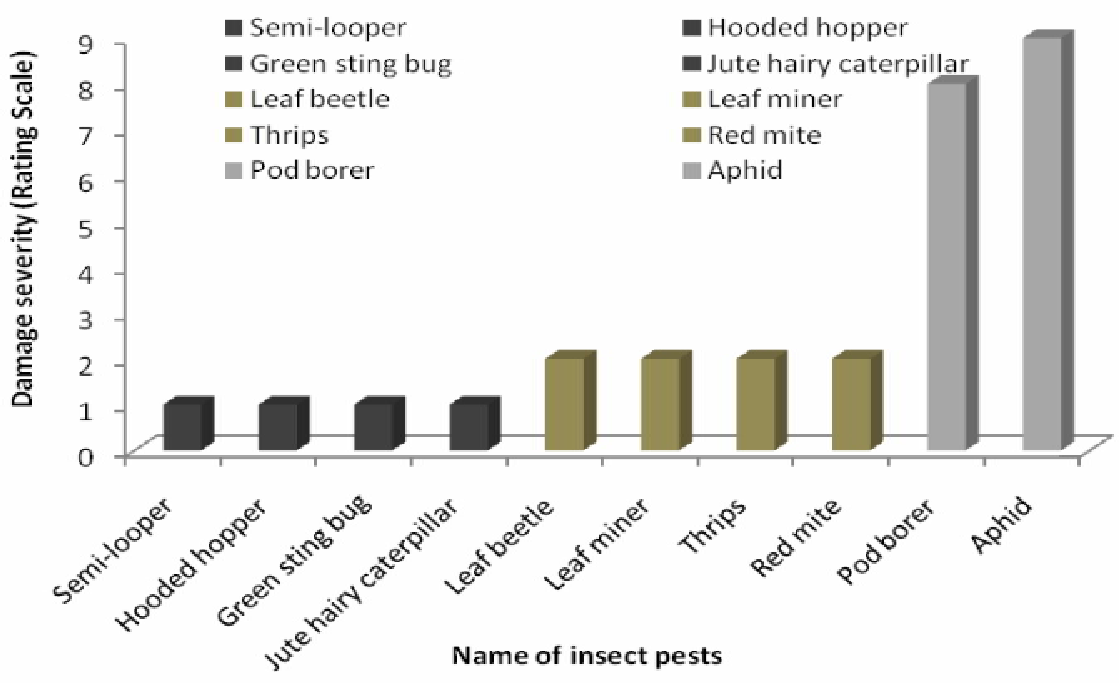

Fig. 1. Pest complex, their level of incidence and damage severity of yard long bean in surveyed areas of Bangladesh

Table 7. Insect pest complex of yard long bean at different growth stages in farmers' field of surveyed areas during kharif season, 2009

\begin{tabular}{|c|c|c|c|c|}
\hline Plant stage & Name of insects & Description of insect & Nature of damage & $\begin{array}{l}\text { Pest } \\
\text { status }\end{array}$ \\
\hline $\begin{array}{l}\text { Vegetative } \\
\text { stage }\end{array}$ & $\begin{array}{l}\text { Leaf beetle } \\
\text { (Unidentified) }\end{array}$ & $\begin{array}{l}\text { Adults were medium, } \\
\text { oval shaped, brownish } \\
\text { yellow back }\end{array}$ & $\begin{array}{l}\text { Made numerous holes } \\
\text { at the lower leaves of } \\
\text { plant }\end{array}$ & Minor \\
\hline $\begin{array}{l}\text { Vegetative } \\
\text { stage }\end{array}$ & $\begin{array}{l}\text { Jute hairy } \\
\text { caterpillar, } \\
\text { Spilosoma obliqua } \\
\text { Lepidoptera }\end{array}$ & $\begin{array}{l}\text { Adults were deep } \\
\text { yellow, dense hairy } \\
\text { body and brownish } \\
\text { black head }\end{array}$ & $\begin{array}{l}\text { Fed on the young } \\
\text { leaves leaving vines }\end{array}$ & Minor \\
\hline $\begin{array}{l}\text { Vegetative } \\
\text { stage }\end{array}$ & $\begin{array}{l}\text { Leaf miner } \\
\text { (Unidentified) }\end{array}$ & $\begin{array}{l}\text { Larvae are small, green } \\
\text { in colour and black } \\
\text { head }\end{array}$ & $\begin{array}{l}\text { Young larvae mine into } \\
\text { the leaf, tunneled it, } \\
\text { feeding and leaving a } \\
\text { transparent leaf blade }\end{array}$ & Minor \\
\hline $\begin{array}{l}\text { Vegetative } \\
\text { and } \\
\text { flowering } \\
\text { stage }\end{array}$ & $\begin{array}{l}\text { Semilooper } \\
\text { (Diachrysia } \text { spp.) } \\
\text { Noctuidae, } \\
\text { Lepidoptera }\end{array}$ & $\begin{array}{l}\text { Caterpillars were green } \\
\text { and formed loop at } \\
\text { motion }\end{array}$ & $\begin{array}{l}\text { Caterpillars fed on } \\
\text { leaves by scratching } \\
\text { green matter leaving } \\
\text { midribs and veins }\end{array}$ & Minor \\
\hline
\end{tabular}




\begin{tabular}{|c|c|c|c|c|}
\hline $\begin{array}{l}\text { Vegetative } \\
\text { and } \\
\text { flowering } \\
\text { stage }\end{array}$ & $\begin{array}{l}\text { Thrips } \\
\text { Megalurothrips } \\
\text { spp. } \\
\text { Thysanoptera }\end{array}$ & $\begin{array}{l}\text { Adult insects were } \\
\text { minute, yellowish } \\
\text { brown, tan or black } \\
\text { with feeble wings. } \\
\text { Nymphs are pale } \\
\text { yellow }\end{array}$ & $\begin{array}{l}\text { Both larvae and adults } \\
\text { attacked unopened } \\
\text { leaves, bud and flower. } \\
\text { Fed on pollen and rasp } \\
\text { other flower parts and } \\
\text { sucked plant juice }\end{array}$ & Minor \\
\hline $\begin{array}{l}\text { Vegetative } \\
\text { and } \\
\text { flowering } \\
\text { stage }\end{array}$ & $\begin{array}{l}\text { Hooded hopper } \\
\text { Leptocentrus } \\
\text { taurus } \\
\text { Membracidae } \\
\text { Hemiptera }\end{array}$ & $\begin{array}{l}\text { The pronotum extended } \\
\text { backward over the } \\
\text { entire abdomen and had } \\
\text { two horn-like processes } \\
\text { laterally }\end{array}$ & $\begin{array}{l}\text { Adults and nymphs } \\
\text { caused damage by } \\
\text { sucking sap from } \\
\text { succulent plant parts }\end{array}$ & Minor \\
\hline $\begin{array}{l}\text { Vegetative } \\
\text { and } \\
\text { flowering } \\
\text { stage }\end{array}$ & $\begin{array}{l}\text { Red mite, } \\
\text { Tetranychus spp. } \\
\text { Tetranychidae } \\
\text { Acarina }\end{array}$ & $\begin{array}{l}\text { Tiny red spiders with } \\
\text { bristly backs hardly } \\
\text { visible with naked eye. } \\
\text { Had eight legs. Spined } \\
\text { small webs on leaves, } \\
\text { twigs and flower buds }\end{array}$ & $\begin{array}{l}\text { Sucks sap from leaves. } \\
\text { Small yellow or brown } \\
\text { spots (stipples) may } \\
\text { also appear on the tops } \\
\text { of the leaves }\end{array}$ & Minor \\
\hline $\begin{array}{l}\text { Flowering } \\
\text { and fruiting } \\
\text { stage }\end{array}$ & $\begin{array}{l}\text { Pod borer, } \\
\text { Euchrysops cnejus } \\
\text { Lycaenidae } \\
\text { Lepidoptera }\end{array}$ & $\begin{array}{l}\text { Male were light purple, } \\
\text { female were heavily } \\
\text { black-dusted with the } \\
\text { wing bases pale shining } \\
\text { blue. Underside is pale } \\
\text { buff with usual } \\
\text { lycaenine markings as } \\
\text { spots and stripe. } \\
\text { Possesses a pair of } \\
\text { string-like tails }\end{array}$ & $\begin{array}{l}\text { Flowers and young } \\
\text { pods with bore holes } \\
\text { and presence of slug } \\
\text { like caterpillar. Larval } \\
\text { entry hole on pod is } \\
\text { plugged with excreta. } \\
\text { Infested pods and } \\
\text { flowers webbed } \\
\text { together }\end{array}$ & Major \\
\hline $\begin{array}{l}\text { Vegetative, } \\
\text { flowering } \\
\text { and fruiting } \\
\text { stage }\end{array}$ & $\begin{array}{l}\text { Aphid, } \\
\text { (Aphis craccivora } \\
\text { Kosh), Aphididae, } \\
\text { Hemiptera }\end{array}$ & $\begin{array}{l}\text { Adults were small in } \\
\text { size, greenish brown, } \\
\text { and brown or black in } \\
\text { colour and occurred } \\
\text { both in alate and } \\
\text { apterous forms }\end{array}$ & $\begin{array}{l}\text { Both adult and nymphs } \\
\text { crowed together in } \\
\text { clusters under leaves, } \\
\text { on twig, inflorescence } \\
\text { and pod. Caused } \\
\text { damage by sucking sap }\end{array}$ & Major \\
\hline $\begin{array}{l}\text { Vegetative, } \\
\text { flowering } \\
\text { and fruiting } \\
\text { stage }\end{array}$ & $\begin{array}{l}\text { Green sting bug, } \\
\text { Nezara viridula, } \\
\text { Pentatomidae, } \\
\text { Hemiptera }\end{array}$ & $\begin{array}{l}\text { Adults shield-shaped, } \\
\text { dull green color, five- } \\
\text { segmented antennae, } \\
\text { dark red or black eyes. } \\
\text { Small black dots along } \\
\text { abdomen sides. Wings } \\
\text { completely covered the } \\
\text { abdomen. Had } \\
\text { malodorous scent }\end{array}$ & $\begin{array}{l}\text { Piercing-sucking } \\
\text { mouthparts. Salivary } \\
\text { fluid pumped down and } \\
\text { liquefied food was } \\
\text { pumped up food canal. } \\
\text { Fed upon all plant parts }\end{array}$ & Minor \\
\hline
\end{tabular}


Results revealed that aphid (Aphid craccivora) and pod borer (Euchrysops cnejus, M. vitrata) occupied the same status (major)in respect of the level of incidence and damage severity in 5 surveyed areas. They were found to cause severe infestation in yard long bean in farmers' field. Semilooper (occupied the lowest status, which did not occur in all the sample areas. Semilooper (Diachrysia orichaicea) was not found in Savar and Shibpurareas while it was observed in Jessore, Chandina and Mirshawrai (Table 6).

\section{Conclusions}

Aphid and pod borers were found as the major insect pests of yard long bean in Jessore, Dhaka, Narsingdi, Comilla and Chittagong districts of Bangladesh. Therefore, appropriate management approaches should be taken to combat aphid and pod borers infestation as well as to increase the yield of yard long bean of those areas.

\section{References}

Anonymous. 2010. Bangladesh Bureau of Statistics. Year book of Agricultural Statistics of Bangladesh $2009 \quad\left(21^{\text {st }}\right.$ edition). Ministry of Planning. Government of the People's Republic of Bangladesh.

Anonymous. 2013. Krishi Diary (in Bengali), Agriculture Information Service, Khamarbari, Farmgate, Ministry of Agriculture, Dhaka, Bangladesh, 73 p.

Dutta N. K., Mian, M. R. U. and Nasiruddin, M. 2004. Development of a management approach against the Pod borer, Euchrysops cnejus (F) attacking stringbean. Bangladesh Agricultural Research Institute (BARI), Joydebpur, Gazipur. Annual Report, 2003-2004, 60$63 \mathrm{pp}$.
Egho, E. O. 2010. Studies on the control of major insect pests and yield of cow pea (Vigna unguiculata (L.) walp under calendar and monitored application of synthetic chemical in ABRAKA, south Nigeria, Archives of Applied Science Research, 2(4), 224-234.

Grubben, G. J. H. 1993. Vigna unguiculata (L.) Walp. cv. group Sesquipedalis. In: Siemonsma, J.S. \& KasemPiluek (Editors). Plant Resources of South-East Asia No 8. Vegetables. Pudoc Scientific Publishers, Wageningen, The Netherlands, 274-278 pp.

Jackai, L. E. N. and Singh, S. R. 1988. Tropical Grain Legume Bulletin, 35, 2-18 pp.

Litsinger, J. A., Quirino, C. B., Lumaban, M. D. and Bandong, J. P. 1977. Grain legume pest complex of three Phillipine ricebased cropping system. Cropping Program, IRRI. Los Banos, Philippines, $39 \mathrm{pp}$.

Purseglove, J. W. 1977. Tropical crops: Dicotyledons. London: Longman Group Ltd, 273-276 pp.

Rahman, M. M., Mannan, M. M. and Islam, M. A. 1981. Pest survey of major summer and winter pulses in Bangladesh. Proceeding of National workshop on Pulses, 18-19 August 1981, BARI, Gazipur, Dhaka.

Rashid, M. A. 1993. Shabji Biggan (in Bengali), Bangla Academy, Dhaka, Bangladesh, $394 \mathrm{pp}$.

Rashid, M. M. 1999. Sabji Biggan (in Bengali). Rashid publishing house, Dhaka, 384-389 pp.

Thaker, B. S., Verma, R., Patibunda, A. and Rawat, R. R. 1984. Chemical control of aphid, Aphis craccivora (Koch) on lentil. Indian Journal of Entomology, 4, 103$104 \mathrm{pp}$. 